\title{
Effects of the COVID-19 Pandemic on the Stress Level of Tsunami- Affected Communities Living in Temporary Housing in Palu City-Indonesia
}

\author{
Rosmala Nur ${ }^{1 *}$, Ulfa Aulia ${ }^{1}$, Muh. Ryman Nafirah ${ }^{1}$, Vidiyanto ${ }^{1}$, Muthia Aryuni ${ }^{2}$, Syaiful Hendra ${ }^{3}$, Hajra Rasmita Ngemba $^{3}$, \\ Muh Rusydi ${ }^{4}$ \\ ${ }^{1}$ Department of Public Health, Faculty of Public Health, Tadulako University, Palu, Indonesia; ${ }^{2}$ Departement of Medicine, Faculty \\ of Medicine, Tadulako University, Palu, Indonesia; ${ }^{3}$ Department of Information Technology, Faculty of Engineering, Tadulako \\ University, Palu, Indonesia; ${ }^{4}$ Department of Geophysics, Faculty of Mathematics and Natural Sciences, Tadulako University, \\ Palu, Indonesia
}

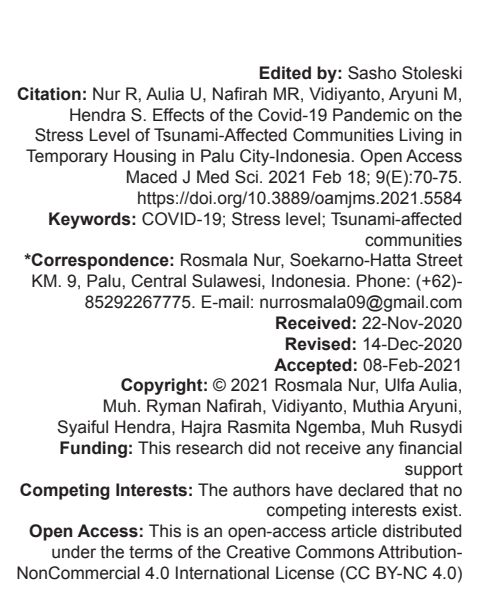

\section{Introduction}

Palu city instituted a lockdown on March 16, 2020 , to contain the virus. It has affected the socioeconomic conditions and the public health in the region. Thelndonesian government categorize the COVID-19 pandemic as a national disaster [1]. In general, both the government and communities place more emphasis on physical aspects in responding to the disaster, such as providing medical assistance, clothing, food, and shelter. Little attention has been paid to the sychiatric/ mental/psychological aspects that lead to posttraumatic stress disorder and that are experienced during the pandemic [2], [3].

The tsunami that struck Palu on September 28, 2018 claimed 3000 lives along with their property. Those who survived were accommodated in the temporary housing, one of which was located in the village of Lere. There were 681 people and 170 family heads living in this place. In addition to losing their property, they also experience post-traumatic stress disorder,which is hard to cure [4].

The mental conditions of the communities living in the temporary housing have not really improved. This is because they have not yet received permanent housing facilities and still feel uncertain about their future livelihoods. This situation worsens amidst the COVID-19 pandemic. The stress of COVID-19, if not dealt with seriously andprofessionally, can lead to mental disorders such as anxiety, depression, psychosis (severe mental disorders), and even to suicide [5], [6]. This study aimed to examine the effect of the COVID-19 pandemic on the stress level of the tsunami-affected 
communities, the strategies to cope with the stress and the COVID-19 protocols being followed.

Although studies on the community stress level have been carried out, their focus is more the effects of work pressure, busyness, and the economy on the stress level of individuals. There has been no research that specifically investigates the effects of the COVID-19 pandemic on the stress level ofthe tsunamiaffected communities in Indonesia. In particular, there is a lack of research that focuses on the conditions of the temporary housing during the pandemic.

\section{Materials and Methods}

\section{Research design, setting dan sample}

This research employed analytical survey method. It was carried out in the temporary housing of the village of Lere, Palu, Indonesia. All 681 people and 170 households in this place participated in this study. The data were gathered during the lockdown, precisely between March 23 and May 23, 2020.

\section{The data collection techniques}

The data were collected using interviews and observations. To measure the stress level of the tsunamiaffected communities, the DASS-42 questionnaire was used.

\section{The data analysis techniques}

The data were analyzed using the paired t-test and percentage analysis.

\section{Results}

\section{Socio-demographic characteristics of the respondents}

This study used six socio-demographic characterstics, namely, age, occupation, income, education, number of family members, and length of stay in the temporary housing.

Table 1 shows that the people affected by the tsunami are generally aged 20-35 (56.7\%). This indicates that most respondentswere still young. In terms of employment, most of them work as a fisherman $(88.8 \%)$ with a low income $(<500,000$ rupiah) $(53.3 \%)$. This data suggest that the average respondents have a low, non-permanent income. Furthermore, in terms of the level of education, most of them only attended
Table 1: Respondents distribution based on the sociodemographic characteristics

\begin{tabular}{|c|c|c|}
\hline Characteristics & Frequency & Percentage \\
\hline \multicolumn{3}{|l|}{ Age } \\
\hline$<20$ years & 68 & 40.0 \\
\hline $20-35$ years & 96 & 56.7 \\
\hline$>35$ years & 6 & 3.3 \\
\hline Total & 170 & 100 \\
\hline \multicolumn{3}{|l|}{ Occupation } \\
\hline Fishermen & 151 & 88.8 \\
\hline Entrepreneur & 17 & 10.0 \\
\hline Farmer & 2 & 1.2 \\
\hline Total & 170 & 100 \\
\hline \multicolumn{3}{|l|}{ Income } \\
\hline High $(<500,000)$ & 90 & 53.3 \\
\hline Middle $(500,000-1,000,000)$ & 40 & 23.3 \\
\hline Low $(<1000,000)$ & 40 & 23.3 \\
\hline Total & 170 & 100 \\
\hline \multicolumn{3}{|l|}{ Education } \\
\hline Elementary school & 90 & 53.3 \\
\hline Junior high school & 40 & 23.3 \\
\hline Senior high school< & 40 & 23.3 \\
\hline Total & 170 & 100 \\
\hline \multicolumn{3}{|l|}{ Number of Family Members } \\
\hline$\geq 2$ & 2 & 1.2 \\
\hline$<3$ & 168 & 98.8 \\
\hline Total & 170 & 100 \\
\hline \multicolumn{3}{|l|}{ Length of Stay in the Temporary Housing } \\
\hline$<1$ year & 2 & 1.2 \\
\hline 1 year 8 months (since the tsunami on September 28,2018 ) & 168 & 98.8 \\
\hline Total & 170 & 100 \\
\hline
\end{tabular}

elementary school education (53.3\%), meaning that they have low education. Meanwhile, $98.8 \%$ of all respondents have families with three members, meaning that on average these respondentslive with many family members. Meanwhile, the majority of them $(98.8 \%)$ have stayed in the temporary housing for 1 year and 8 months since the tsunami on September 28 , 2018. This data show that in general they have been living in the temporary housing for quite a long time.

\section{The effects of the COVID-19 pandemic on the stress level of the tsunami-affected communities}

Table 2 shows the percentage of respondentsaccording to their stress level. The majority of the respondents $(60 \%)$ experienced moderate level of stress while only $5 \%$ suffered from severe level of stress.

Table 2: Percentage of respondents based on the stress level

\begin{tabular}{lcc}
\hline Stress level & $f$ & $\%$ \\
\hline Mild & 60 & 35 \\
Moderate & 84 & 60 \\
Severe & 26 & 5 \\
Total & 170 & 100 \\
\hline
\end{tabular}

Table 3 shows the statistical test results in which losing jobs during the pandemic is correlated with the stress level of the tsunami-affected communities, with $p=0.002$. It is also the case for other factors, namely, decreasing income, no job vacancy, reduced government assistance during the pandemic, and uncertainty over the end of the pandemic which, respectively, obtain $p$-values of $0.0016,0.012,0.000$, and 0.001 ( $p<\alpha 0.05$ ). It can be concluded that these variables affected the stress level of the communities. 
Table 3: The effects of the COVID-19 Pandemic on the stress level of the tsunami-affected communities living in the temporary housing

\begin{tabular}{|c|c|c|c|c|c|c|c|}
\hline \multirow[t]{3}{*}{ Effects of the Covid-19 pandemic } & \multicolumn{6}{|c|}{ Stress } & \multirow[t]{3}{*}{$p$ value } \\
\hline & \multicolumn{2}{|c|}{ Mild } & \multicolumn{2}{|c|}{ Moderate } & \multicolumn{2}{|c|}{ Severe } & \\
\hline & $\bar{F}$ & $\%$ & $\bar{F}$ & $\%$ & $\bar{F}$ & $\%$ & \\
\hline Losing jobs & & & & & & & 0.002 \\
\hline Yes & 16 & 26.6 & 52 & 61.9 & 14 & 53.8 & \\
\hline No & 44 & 73.4 & 32 & 38.1 & 12 & 46.2 & \\
\hline Total & 60 & 100 & 84 & 100 & 26 & 100 & \\
\hline Decreasing income & & & & & & & 0.0016 \\
\hline Yes & 34 & 56.6 & 54 & 64.3 & 13 & 50 & \\
\hline No & 26 & 43.4 & 30 & 35.7 & 13 & 50 & \\
\hline Total & 60 & 100 & 84 & 100 & 26 & 100 & \\
\hline No job vacancy & & & & & & & 0.0012 \\
\hline Yes & 41 & 68.3 & 49 & 58.3 & 14 & 53.8 & \\
\hline No & 19 & 31.7 & 35 & 41.7 & 12 & 46.2 & \\
\hline Total & 60 & 100 & 84 & 100 & 26 & 100 & \\
\hline Reduced government assistance & & & & & & & 0.000 \\
\hline Yes & 39 & 65 & 66 & 78.6 & 14 & 53.8 & \\
\hline No & 21 & 35 & 18 & 21.4 & 12 & 46.2 & \\
\hline Total & 60 & 100 & 84 & 100 & 26 & 100 & \\
\hline Uncertainty over the end of pandemic & & & & & & & 0.001 \\
\hline Yes & 37 & 61.7 & 57 & 67.8 & 15 & 57.5 & \\
\hline No & 23 & 38.3 & 27 & 32.2 & 11 & 42.3 & \\
\hline Total & 60 & 100 & 84 & 100 & 26 & 100 & \\
\hline
\end{tabular}

\section{Strategies for coping with stress}

Table 4 shows that the strategies that these respondents used to cope with stresswere socializing with neighbors $(100 \%)$, breaking the Ramadan fast together $(100 \%)$, attending congregational prayers $(100 \%)$, promoting mutual cooperation $(100 \%)$, and working together $(40 \%)$. It indicates that they did not obey the COVID-19 protocols.

Table 4: Analysis of the respondensbased on their strategies for coping with stress

\begin{tabular}{lll}
\hline Coping with stress & $\mathrm{f}$ & $\%$ \\
\hline Socializing with neighbors & 170 & 100.0 \\
Working together & 68 & 40.0 \\
Breaking the Ramadan fast together & 170 & 100.0 \\
Attending congregational prayers & 170 & 100.0 \\
Promoting mutual cooperation & 170 & 100.0 \\
\hline
\end{tabular}

\section{The COVID-19 protocols}

Table 5 indicates that the tsunami-affected communities living in the temporary housing did not obey the COVID-19 protocols because they did not wear a mask, do physical distancing, wash their hands nor follow stay-at-home orders.

Table 5: Analysis of the respondentsin relation to the COVID-19 protocols

\begin{tabular}{lll}
\hline Preventive actions & $\mathrm{f}$ & $\%$ \\
\hline Did not wear a mask & 170 & 100.0 \\
Did not do physical distancing & 170 & 100.0 \\
Did not stay at home & 170 & 100.0 \\
Did not wash hands & 170 & 100.0 \\
\hline
\end{tabular}

\section{Discussion}

\section{The effects of the COVID-19 pandemic on the stress level}

Based on the statistical analysis of the respondents' stress level, it was found that the majority of them experienced moderate level of stress $(60 \%)$, followed by those with mild stress (35\%) and severe stress $(5 \%)$. Most of the respondents who suffered from moderate stress cited some factors contributing to their stress level, namely, reduced government assistance during the pandemic $(78.6 \%)$, uncertainty over the end of the pandemic $(67.8 \%)$, decreasing income $(64.3 \%)$, losing jobs $(61.9 \%)$, and difficulty to find job vacancies $(58.3 \%)$. This is in line with an argument [7], [8] that the majority of the victims of a disaster, such as COVID-19, will suffer from relatively severe stress and anxieties with regard to fulfilling their daily needs such as food and medicine. Furthermore, some studies have also found that there is a relationship between COVID-19 and the stress level. Their findings indicate that the pandemic has made people lose jobs which, in turn, make them stressful [9]; changes in the economic status of the communities due to COVID-19 significantly contribute to the individuals' psychological conditions [8]; and job loss raises feelings of helplessness and stress because they cannot meet family needs [10].

Any disasters including the COVID-19 pandemic and disasters caused by human actions such as technological disasters, mass violence, and famine have a very significant impact on changes in physical, psychological, social, and economic aspects of human life [10], [11].

Statistical test results show that job losses due to the pandemic affected the stress level of the tsunamiaffected communities $(p=0.002)$. This is because they want to fulfill the daily needs but are unable to do so because they do not have any jobs. This finding is in line with a research result [12] showing that unemployed people have higher rate of anxiety and depression. Losing a job will cause anger and depressive symptoms for everyone. These findings indicate that interventions to help tsunami-affected communities who lost their jobs become a solution to prevent stress [13].

The COVID-19 pandemic decreased the income of the respondents $(p=0.0016)$. This is probably because some of them have lost their jobs and is unable to do innovations due to the limited access they have during the pandemic. The decrease in their income is the main trigger which has a negative impact on their mental health. Most studies note that increasing unemployment, reducing staff, and reducing wages are associated with increased rates of mood, anxiety, depression, dystrophyia, and suicide [14]. The COVID-19 pandemic mediates the relationship between financial pressures and stress symptoms that occur [15].

The difficulty of finding job opportunities during the pandemic affected the stress level of the respondents $(p=0.0012)$. This condition is related to the income level of the communities. This is in accordance with a research result [16] showing that the inability of job seekers to find job openings will contribute to their deteriorating health. A number of 
factors are associated with high stress levels, including one of which is the difficulty of getting a job [17]. This is an important finding related to the impact of the COVID-19 pandemic on tsunami-affected communities that may be a reference for the government in creating jobs, especially those related to creative industries in the temporary housing.

Reduced government assistance affected the respondents' stress level $(p=0.00)$. Numerous studies show that government social support is very important to maintain the physical and psychological health of the communities. Government social support can reduce theirsusceptibility to the stress. Food aid from the government such as rice and side dishes can fulfill their daily needs so that their burden will be reduced which then affects their central oxytocin hormone [18]. Helping others can specifically prevent someone from becoming stressful [19].

Uncertainy over the end of the pandemic affected the respondents' stress level ( $p=0.002)$. Individuals with high intolerance to uncertainty are more likely to perceive a pandemic as a threat and are also more likely to use coping strategies that focus on emotions. Both of these factors increase a person's stress level. The uncertainty about when the pandemic ends has implications for physical health and psychological distress [12], [20]. The body's immunity, which is very important for dealing with stress during the coronavirus pandemic and certainty about when the pandemic ends are some of the urgent needs that can help us to increase our resilience [21], [22].

\section{Strategies for coping with stress}

The findings show that all respondents coped with stress by socializing with neighbors, working together, breaking the Ramadan fast together, attending congregational prayers, and promoting mutual cooperation. These coping strategies are at odds with the COVID-19 protocols. This happens because there is a general belief or a culture that if a disaster occurs, people will panic. However, the response to the COVID-19 outbreak was different because it actually increased cooperation and orderly behavior according to the norm. The concept of panic has shifted to focus on how people work together rather than having to compete in the face of crises, the emergence of a shared identity, and concern for others by bringing up shared experiences of dealing with problems. A strong sense of shared social identity will help coordinate efforts to manage threats and foster commitment in the group and adherence to norms [23], [24].

These findings are in line with an article [25] about how to cope with stress using problem-focused coping and seeking social support in the form of information, real, and emotional supports. In this case, the respondents did many activities together such as socializing with neighbors, promoting mutual cooperation, and attending congregational prayers as a coping mechanism. The major finding of this study is that people in the temporary housing coped with their stress during the pandemic with strategies that were at odds with the COVID-19 protocols.

\section{COVID-19 preventive measures}

The statistical test results show that most respondents did not obey the COVID-19 protocols. This is because the majority of them believe that they have a strong immune system as a result of bathing in the sea. In addition, they also assume that they are a big family that has never been visited by outsiders or foreigners. In fact, judging from their homes and sanitation, they are among the vulnerable groups who can be infected by the coronavirus. Their houses are attached to each other, with an area of only $2 \times 3$ meters inhabited by an average of 4-5 people. Seeing this condition, they should be more disciplined in complying with the COVID-19 protocol.

This condition can certainly help maintain their mental health. Efforts to recover from psychological shocks or unfavorable conditions require an ability known as resilience [8]. Resilience is the ability of individuals to respond and deal positively with unpleasant conditions, do something to strengthen themselves, and rise from adversity, which is seen as something that can be overcome [26]. Resilience is closely related to individual coping strategies. This is in accordance with the argument [27] that the level of resilience is related to the ability to manage stress and emotions and choose certain coping strategies to overcome problems that arise even though it is not always in accordance with general norms that must be obeyed. Their reluctance to comply with the COVID-19 protocols is related to a specific coping strategy, namely, efforts that involve cognitive, emotional, and behavioral aspects to control and reduce problems that can cause stress [28].

\section{Conclusion}

The COVID-19 pandemic affected the stress level of the tsunami-affected communities living in temporary housing in Palu, Indonesia. They used some strategiesto cope with their stress such as by socializing with neighbors, attending congregational prayers, and promoting mutual cooperation. However, they did not follow the COVID-19 protocols such as wearing a mask, physical distancing, hand washing, and staying at home. 


\section{Author Contribution}

RosmalaNur (conceptualizing and designing the study, preparing the manuscript draft, doing revisions or providing critique), Muh.Ryman Nafirah (sectional scientific management), Ulfa (analyzing and interpreting the data) Vidiyanto (analyzing and interpreting the data), MuthiaAryuni (analyzing and interpreting the data) Syaiful Hendra (sectional scientific management); Hajra Rasmita Ngemba (data analysis and interpretation); Muh. Rusydi, H (sectional scientific management);

\section{Significance Statement}

This study found that the COVID-19 pandemic affected the stress level of tsunami-affected communities living in temporary housing in Palu, Indonesia. The strategies for coping with this stress were socializing with neighbors, working together, breaking the Ramadan fast together, attending congregational prayers, and promoting mutual cooperation. However, these communities did not obey the COVID-19 protocols.

\section{References}

1. Wibowo A. President of Indonesia Republic Sets COVID-19 as a National Disaster, in Indonesia; 2020. Available from: https:// www.bnpb.go.id/berita/presiden-tetapkan-covid19-sebagaibencana-nasional. [Last accessed 13 Apr 2020].

2. Wibowo A. Dampak Psikologis Corona Butuh Perhatian, Badan Penanggulangan Bencana Nas; 2020. Available from: https://www.nasional.sindonews.com/read/23791/15/ dampak-psikologis-corona-butuh-perhatian-1589151913. [Last accessed 11 May 2020]

3. Gorrochategi MP, Eiguren A, Student M, Dosil M, Student S, Etxebarria NO. Stress, anxiety, and depression in people aged over 60 in the COVID-19 outbreak in a sample collected in Northern Spain. Am J Geriatr Psychiatry. 2020;28(9):993-8. https://doi.org/10.1016/j.jagp.2020.05.022 PMid:32576424

4. Committee IS. Catatan Tentang Aspek Kesehatan Jiwa dan Psikososial Wabah; 2020. p. 1-20.

5. Banerjee A, Czinn SJ, Reiter RJ, Blanchard TG. Crosstalk between endoplasmic reticulum stress and anti-viral activities: A novel therapeutic target for COVID-19. Life Sci. 2020;255:117842. https://doi.org/10.1016/j.lfs.2020.117842 PMid:32454157

6. Bromet EJ, Atwoli L, Kawakami N, Navarro-Mateu F, Piotrowski $\mathrm{P}$, King AJ, et al. Post-traumatic stress disorder associated with natural and human-made disasters in the world mental health surveys. Psychol Med. 2017;47(2):227-41. https://doi. org/10.1017/s0033291716002026

PMid:27573281
7. Gallagher HC, Richardson J, Forbes D, Harms L, Gibbs L, Alkemade $\mathrm{N}$, et al. Mental Health following separation in a disaster: The role of attachment. J Trauma Stress. 2016;29(1):56-64. https://doi.org/10.1002/jts.22071 PMid:26749321

8. Brooks SK, Dunn R, Amlôt R, Rubin GJ, Greenberg N. Socia and occupational factors associated with psychological wellbeing among occupational groups affected by disaster: A systematic review. J Ment Health. 2017;26(4):373-84. https:// doi.org/10.1080/09638237.2017.1294732 PMid:28635439

9. Sodhi MM. Natural disasters, the economy and population vulnerability as a vicious cycle with exogenous hazards. J Oper Manag. 2016;45:101-13. https://doi.org/10.1016/j. jom.2016.05.010

10. Mulchandani R, Smith M, Armstrong B, Beck CR, Oliver I, Davidwaite $\mathrm{T}$, et al. Effect of insurance-related factors on the association between flooding and mental health outcomes. Int J Environ Res Public Health. 2019;16(7):1174. https://doi. org/10.3390/ijerph16071174 PMid:30986906

11. Abdulah DM, Health P, Musa DH, Facs MF, Surgery A. Insomnia and stress of physicians during COVID-19 outbreak. Sleep Med. 2020;2:100017. https://doi.org/10.1016/j.sleepx.2020.100017

12. Navarro-Abal Y, Climent-Rodríguez JA, López-López MJ, Gómez-Salgado J. Psychological coping with job loss. Empirical study to contribute to the development of unemployed people. Int J Environ Res Public Health. 2018;15(8):1787. https://doi. org/10.3390/ijerph15081787

PMid:30127282

13. Shing EZ, Jayawickreme E, Waugh CE. Contextual positive coping as a factor contributing to resilience after disasters. $J$ Clin Psychol. 2016;72(12):1287-306. https://doi.org/10.1002/ jclp.22327

PMid:27410521

14. Mucci N, Giorgi G, Perez JF, Arcangeli G. The correlation between stress and economic crisis: A systematic review. Neuropsychiatr Dis Treat. 2016;12:983-93. https://doi.org/10.2147/ndt.s98525 PMid:27143898

15. Jackowski SA, Baxter-jones AD, Mclardy AJ, Pierson RA, Rodgers CD. The associations of exposure to combined hormonal contraceptive use on bone mineral content and areal bone mineral density accrual from adolescence to young adulthood: A longitudinal study. Bonr Rep. 2016;5:e333-41. https://doi.org/10.1016/j.bonr.2015.06.001

PMid:28580404

16. Thorsteinsson EB, Brown RF, Richards C. The relationship between work-stress, psychological stress and staff health and work outcomes in office workers. Psychology. 2014;5(10):1301-11. https://doi.org/10.4236/ psych.2014.510141

17. Rahman $A E$, Perkins J, Islam $S$, Siddique $A B$, Anwar MR, Mazumder $\mathrm{T}$, et al. Knowledge and involvement of husbands in maternal and newborn health in rural Bangladesh. BMC Pregnancy Childbirth. 2018;18(1):247. https://doi.org/10.1186/ s12884-018-1882-2

PMid:29914410

18. Ozbay F, Johnson DC, Dimoulas E, Morgan CA, Charney D, Southwick S. Social support and resilience to stress: From neurobiology to clinical practice. Psychiatry (Edgmont). 2007;4(5):35-40. https://doi.org/10.2105/ajph.2012.300876 PMid:20806028

19. Poulin MJ, Brown SL, Dillard AJ, Smith DM. Giving to others and the association between stress and mortality. Am J Public Health. 2013;103(9):1649-55. 


\section{PMid:23327269}

20. Dewa CS, Thompson AH, Jacobs P. Relationships between job stress and worker perceived responsibilities and job characteristics. Int J Occup Environ Med. 2011;2(1):37-46.

\section{PMid:23022817}

21. Vinkers $\mathrm{CH}$, van Amelsvoort $\mathrm{T}$, Bisson JI, Branchi I, Cryan JF, Domschke $\mathrm{K}$, et al. Stress resilience during the Coronavirus pandemic. Eur Neuropsychopharmacol. 2020;35:12-6. https:// doi.org/10.1016/j.euroneuro.2020.05.003

PMid:32446705

22. Kenneth M, Apostolopoulos $Y$, Sevil S. Syndemic frameworks to understand the effects of COVID-19 on commercial driver stress, health, and safety. J Transp Health. 2020;18:100877. https://doi.org/10.1016/j.jth.2020.100877

PMid:32501420

23. Lunn PD, Belton CA, Timmons S, Robertson D. Using behavioural science to help fight the Coronavirus: A rapid, narrative review. J Behav Public Adm. 2020:3(1):1-15.
24. van Bavel JJ, Baicker K, Boggio PS, Capraro V, Cichocka A Cikara M, et al. COVID-19 pandemic response. Nat Hum Behav. 2020;4(5):460-71.

PMid:32355299

25. Rabenu E, Yaniv E, Elizur D. The relationship between psychological capital, coping with stress, well-being, and performance. Curr Psychol. 2017;36:875-87. https://doi. org/10.1007/s12144-016-9477-4

26. Djalante $R$, Shaw $R$, DeWit $A$. Building resilience against biological hazards and pandemics: COVID-19 and its implications for the sendai framework. Prog Disaster Sci. 2020;6:100080. https://doi.org/10.1016/j.pdisas.2020.100080

27. Kumala DL, Dartanto T. Natural disasters and girls vulnerability: Is child marriage a coping strategy of economic shocks in Indonesia? Vulnerable Child Youth Stud. 2019;14(1):24-35 https://doi.org/10.1080/17450128.2018.1546025

28. Sibony A. The UK COVID-19 response: A behavioural irony? Eur J Risk Regul. 2020;11(2):350-7. https://doi.org/10.1017/ err.2020.22 